\title{
Game Edukasi Pengenalan Nama Buah Dalam Bahasa Inggris Menggunakan RPG Maker MV
}

\author{
Denny Firmansyah ${ }^{1^{*}}$, Martini $^{2}$, Hidayanti Murtina ${ }^{3}$ \\ 1,3 Teknik Informatika; STMIK Nusa Mandiri Jakarta; Jl. Raya Jatiwaringin No 2 RT 08 RW 013 \\ Kelurahan Cipinang Melayu Kacamatan Makasar Jakarta timur 13620, telp (021) 8005722; \\ e-mail: dennyfirmansyah62@gmail.com, hidayanti.hym@nusamandiri.ac.id \\ 2 Sistem Informatika; Universitas Bina sarana Informatika; Jl. Kramat Raya No 98 RT 02 RW 09 \\ Kwitang Kecamatan Senen Jakarta Pusat 10450 telp (021) 8000063; \\ e-mail: martini.mtn@bsi.ac.id \\ * Korespondensi: e-mail: dennyfirmansyah62@gmail.com
}

Diterima:06 Oktober 2020; Review:28 November 2020; Disetujui:03 Desember 2020

Cara sitasi: Firmansyah D, Martini, Murtina H. 2020. Game Edukasi Pengenalan Nama Buah Dalam Bahasa Inggris Menggunakan RPG Maker MV. Information Management for Educators and Professionals. 5 (1): 25-34

\begin{abstract}
Abstrak: Seiring dengan perkembangan teknologi di era ini, game juga mengalami perkembangan yang pesat. Tetapi pada umumnya game di Indonesia dinilai negatif oleh kebanyakan masyarakat. Permasalahanya adalah banyak game yang beredar game-game yang merusak dan tidak ada konten edukasinya, banyak anak-anak yang ketagihan, kecanduan game tersebut sehingga berjam-jam didepan komputer. Padahal jika diarahkan dengan benar dan baik, game bisa dijadikan sarana belajar yang menyenangkan, asik, dan diyakini lebih efektif dari belajar yang hanya membaca saja. Maka dari itu berdasarkan hal tersebut maka dibuatlah game edukasi pengenalan nama buah dalam bahasa Inggris menggunakan RPG Maker MV, adapun metode penelitian yang digunakan dalam pembuatan game edukasi ini yaitu dengan cara Observasi dan studi pustaka. Metode pengembangan menggunakan metode Multimedia Development Life Cycle (MDLC), Aplikasi ini berbasis Windows (PC/Laptop).
\end{abstract}

Kata Kunci : Buah, Game Edukasi, RPG Maker MV

Abstract: Along with the development of technology in this era, the game also experienced rapid development. But in general the game in Indonesia is considered negative by most people. The problem is that many games are circulating, destructive games and no educational content, many children are addicted, addicted to the game so many hours in front of the computer. Yet if directed correctly and well, games can be used as a fun, cool learning tool, and are believed to be more effective than learning that only reads it. Therefore based on this, make educational game intoduce the name of fruits in English was made using RPG Maker MV, as for the research methods used in making this educational game that is by observation and literature study. The development method uses the Multimedia Development Life Cycle (MDLC), this application is based on Windows (PC / Laptop).

\section{Keywords: Fruits, Game Educational, RPG Maker MV}

\section{Pendahuluan}

Game merupakan salah satu produk teknologi informasi yang cukup digemari saat ini. Game juga bisa merupakan bentuk aplikasi yang edukatif, artinya bisa dijadikan sebagai media pembelajaran dimana prosesnya bisa dilakukan dengan konsep belajar sambil bermain. "Game edukasi, adalah permainan yang dirancang atau dibuat untuk merangsang daya pikir termasuk meningkatkan konsentrasi dan memecahkan masalah. Edugame juga merupakan permainan 
yang digunakan dalam proses pembelajaran, permainan tersebut mengandung unsur mendidik atau nilai-nilai pendidikan" [7].

"Pada saat anak belajar dengan metode konvensional maka anak akan susah memahami dan cepat bosan karena anak belajar dari buku dan mendengarkan guru menjelaskan tetapi dengan adanya game edukasi sebagai media pembelajaran yang interaktif maka diharapkan akan memudahkan anak dalam mempelajari, memahami dan menguasai bahasa asing khususnya bahasa Inggris"[8]. "Sementara tipe game sendiri belum banyak menyediakan game edukasi yang digemari anak. Penelitian ini dilakukan untuk melihat adanya hubungan antara adiksi game dengan keaktifan pembelajaran anak" [9]. "Game dapat dimanfaatkan oleh masyarakat dan kaum pendidik sebagai media untuk menyampaikan berbagai jenis pendidikan dan pembelajaran tentang budaya yang menarik dan menyenangkan" [10].

Pada penelitian ini akan dilakukan analisis pengaruh game edukasi pada kemampuan dalam menguasai kosakata bahasa asing, dengan studi kasus bahasa Arab. Game edukasi tersebut menggunakan perangkat bergerak dan salah satunya menggunakan teknologi realitas virtual dengan kakas Google Cardboard. Game edukasi diujikan pada pengguna berusia 10-15 tahun dan dibagi menjadi dua kelompok, berdasarkan teknologi yang digunakan dan genre game. Pengguna melakukan pre-test dan post-test untuk mengukur kemampuan mereka sebelum dan sesudah mengujikan game. Hasil pengujian tersebut dianalisis dengan metode uji hipotesis ANOVA. Dari kedua kelompok tersebut didapatkan kesimpulan bahwa perbedaan teknologi tidak berpengaruh secara signifikan terhadap kemampuan pengguna. Begitu pula pada kelompok kedua, didapatkan kesimpulan bahwa faktor jenis game, faktor jenis kelamin pengguna, dan hubungan kedua faktor tersebut tidak berpengaruh secara signifikan terhadap perubahan kemampuan pengguna dalam menguasai perbendaharaan kosakata bahasa Arab [1].

Hasil dari penelitian dapat diketahui bahwa game edukasi bahasa Inggris "Adventure of Frunimal" berhasil dikembangkan dengan game engine Construct2 dengan metode pengembangan Multimedia Luther. Pengujian pada aspek functional suitability sudah memenuhi standar AQuA, pada aspek performance efficiency sudah memenuhi ambang batas aman yang ditetapkan oleh Little Eye dan tidak terjadi memory leak, pada aspek compatibility dapat berjalan pada OS Android dari versi Ice Cream Sandwich sampai Marshmallow, dan pada aspek usability secara keseluruhan didapatkan hasil baik dalam hal kegunaan, mudah digunakan dan dipelajari serta memuaskan [2].

Penelitian ini mengunakan teknik kualitatif yang digunakan untuk menguji kelayakan dari aplikasi ini. Untuk pembuatan program aplikasi peneliti menggunakan adobe Macromedia Flash Profesional 8. Kesimpulan hasil penelitian ini adalah (1) Telah berhasil dibuat sebuah aplikasi game edukasi untuk membantu guru bahasa inggris agar bisa membantu dalam penyampaian pelajaran ekstra kurikuler bahasa inggris untuk kelas 4. (2) Pengaruh aplikasi ini terhadap minat dan semangat belajar siswa berdasarkan pengujian yang telah dilakukan dan setelah di hitung menggunakan SPSS memiliki cronbach's Alpha sebesar 0,813 dimana jika dilihat pada tingkat reliabilitas data menunjukkan kriteria reliabilias tinggi. Berdasarkan simpulan hasil penelitian ini, direkomendasikan : (1) Game dalam aplikasi ini diharapkan dapat lebih bervariasi lagi bentuknya. (2) Penyempurnaan cerita dengan menambah fitur animasi dari semua permainan. (3) Penyempurnaan desain interface lebih menarik lagi [3].

Namun, pada umumnya game yang ada di Indonesia dinilai negatif oleh kebanyakan masyarakat. Permasalahannya adalah banyak game yang beredar adalah game-game yang merusak dan yang tak ada konten edukasi di dalamnya. Banyak anak-anak yang ketagihan game yang merusak tersebut, sehingga mereka berjam-jam duduk di depan komputer, play station dan semacamnya. Padahal jika diarahkan dengan benar dan baik, game bisa menjadi sarana belajar yang menyenangkan dan diyakini lebih efektif.

Solusi yang diusulkan untuk menyelesaikan masalah tersebut salah satunya dengan cara penulis membangun sebuah aplikasi mengenai game edukasi dengan judul "Pembuatan game edukasi pengenalan nama buah-buahan dalam bahasa Inggris menggunakan RPG Maker MV". Aplikasi ini berbasis Windows (PC/Laptop), menggunakan metode Multimedia Development Life Cycle (MDLC). Di dalam game ini pemain diarahkan untuk mengelilingi desa dan memasuki ruang-ruang untuk melihat kebun, isi dalam rumah, buah-buahan serta deskripsi tentang buah beserta pengucapan buah tersebut pada saat sudah melihat buahbuahan yang ada. pemain akan diberikan pertanyaan seputar buah-buahan yang sudah dilihat oleh pemain, sehingga informasi tersebut bisa menambah wawasan. 


\section{Metode Penelitian}

Dalam penulisan ini penulis menggunakan metode penelitian observasi dan studi pustaka. Pengembangan dilakukan dengan metode Multimedia Development Life Cycle (MDLC) yang mempunyai 6 tahapan, yaitu [5]:

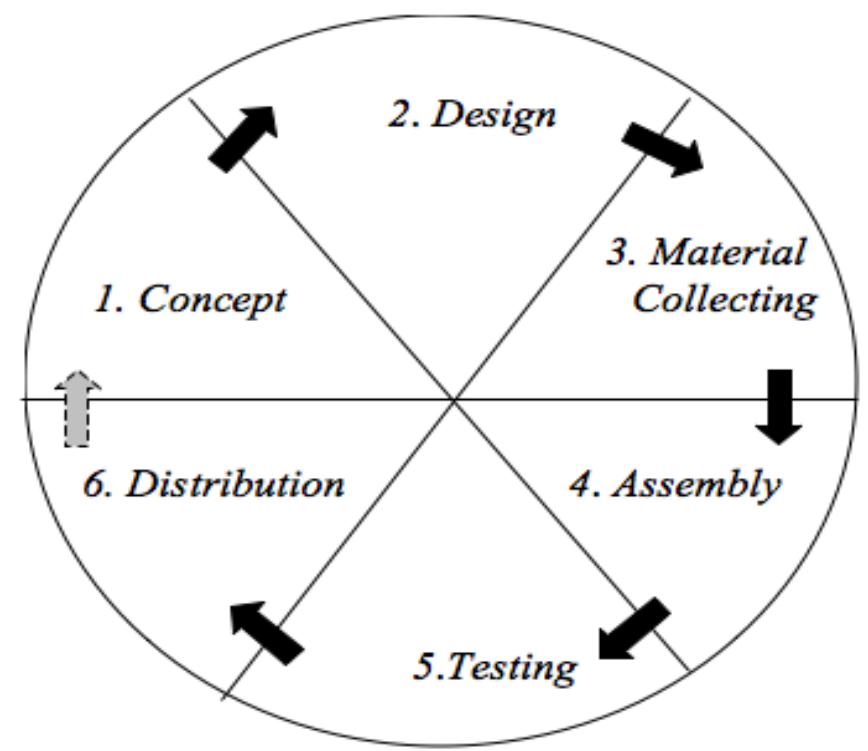

Sumber: Perancangan game edukasi (2020)

Gambar 1. Multimedia Development Life Cycle (MDLC)

Pertama Concept (Konsep) yaitu Genre game ini adalah education karena kontennya mengandung unsur edukasi tentang pengenalan nama-nama buah dalam bahasa Inggris. Game ini bisa berjalan pada platform yaitu PC/laptop berbasis windows dan bisa dimainkan oleh anak umur 7-10 tahun. Konsep dasar dari game ini adalah permainan menjelajah peta dan menerima misi pencarian (quest) dari NPC (Non Playable Character), jika sudah menyelesaikan misi pencarian sebelumnya dan menerima misi/quest pencarian dari NPC lain tingkat kesulitan level quest akan naik, akan ada Informasi buah beserta pengucapan buat tersebut, dan akan ada event pertanyaan/quiz. game ini tidak terdapat unsur kekerasan yang diperlihatkan.

Kedua Design (Desain) yaitu Pada tahap desain game ini dirancang dengan desain grafik langkah suatu program, representasi antarmuka, dan menggunakan Story board. sistem menggunakan diagram UML (Unified Modeling Language) "UML merupakan bahasa visual untuk permodelan dan komunikasi mengenai sebuah sistem dengan menggunakan diagram dan teks-teks pendukung" [4], diantaranya use case diagram, sequence diagram, activity diagram.

Ketiga Obtaining Content Material (pengumpulan material) yaitu Pada tahap ini membutuhkan software RPG maker MV dan file-file multimedia seperti perekam audio dengan format ogg, dan icon gambar dengan format png untuk input materi pada game yang akan dibuat.

Keempat Assembly (Penyusunan dan Pembuatan) yaitu Pada tahap ini penulis melakukan penyusunan plugin beserta pengkodean yang digunakan RPG maker MV menjadi desain dan event di dalam game serta menjadi sebuah materi pembelajaran.

Kelima Testing (Uji coba) yaitu Tahap Pengujian game dilakukan untuk mengetahui kesesuaian spesifikasi game dan dampaknya bagi pemain. Adapun metode pengujian yang digunakan adalah teknik Black Box Testing.

Keenam Distribution (Menyebar Luaskan) yaitu Tahap penggandaan dan penyebaran game pengenalan nama-nama buah dalam bahasa Inggris kepada pengguna melalui CD/DVD.

Sedangkan pengujian penulis menggunakan metode blackbox testing. "Pengujian black box, juga disebut pengujian perilaku, berfokus pada persyaratan fungsionalperangkat lunak. Artinya, teknik pengujian black box memungkinkan Anda untuk mendapatkan set kondisi input yang sepenuhnya akan menjalankan semua persyaratan fungsional untuk suatu program" [6]. 


\section{Hasil dan Pembahasan}

Hasil dan pembahasan dari penelitian ini, antara lain:

Pertama Analisa Kebutuhan Sistem yang terdiri dari Pemain bisa pilih New Game, Pemain bisa pilih Continue, Pemain bisa pilih Options

Kedua Desain, dalam penelitian ini desain sistem menggunakan UML meliputi pembuatan use case diagram, activity diagram, user interface, storyboard dan material. Perancangan perangkat lunak sistem diantaranya perancangan basis data menghasilkan pemetaan tabel-tabel yang digambarkan dengan Entity Relationship Diagram. Desain user interface yang sesuai untuk kebutuhan pengaksesan dan penyampaian informasi kepada pemain atau pengguna.

Ketiga yaitu Desain Sistem yang terdri dari Pertama Use Case Diagram, use case ini menjelaskan tentang kegiatan yang dilakukan oleh pemain pada game edukasi ini.

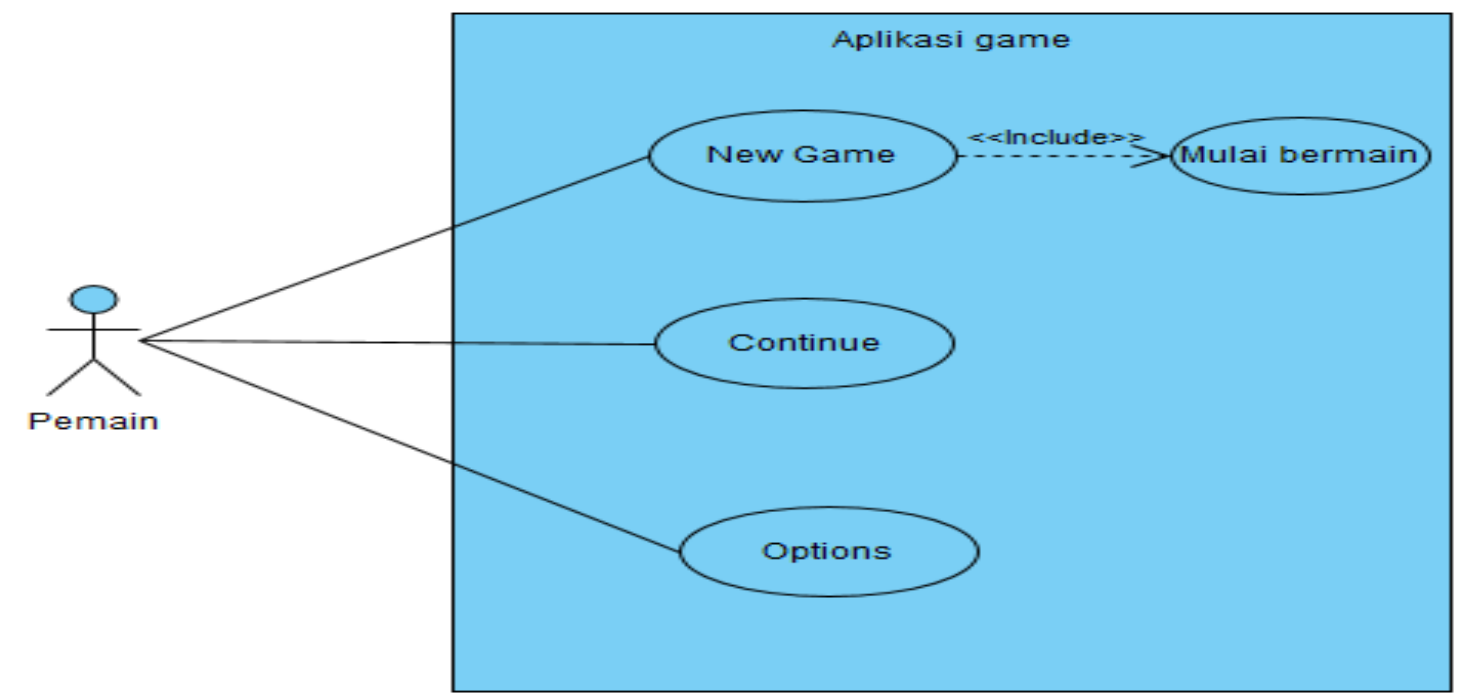

Sumber: Perancangan game edukasi (2020)

Gambar 2. Use Case Diagram Pemain

Kedua Activity Diagram, diagram ini menjelaskan tentang aktivitas memulai permainan yang menampilkan opsi pilihan new game atau keluar dari permainan.

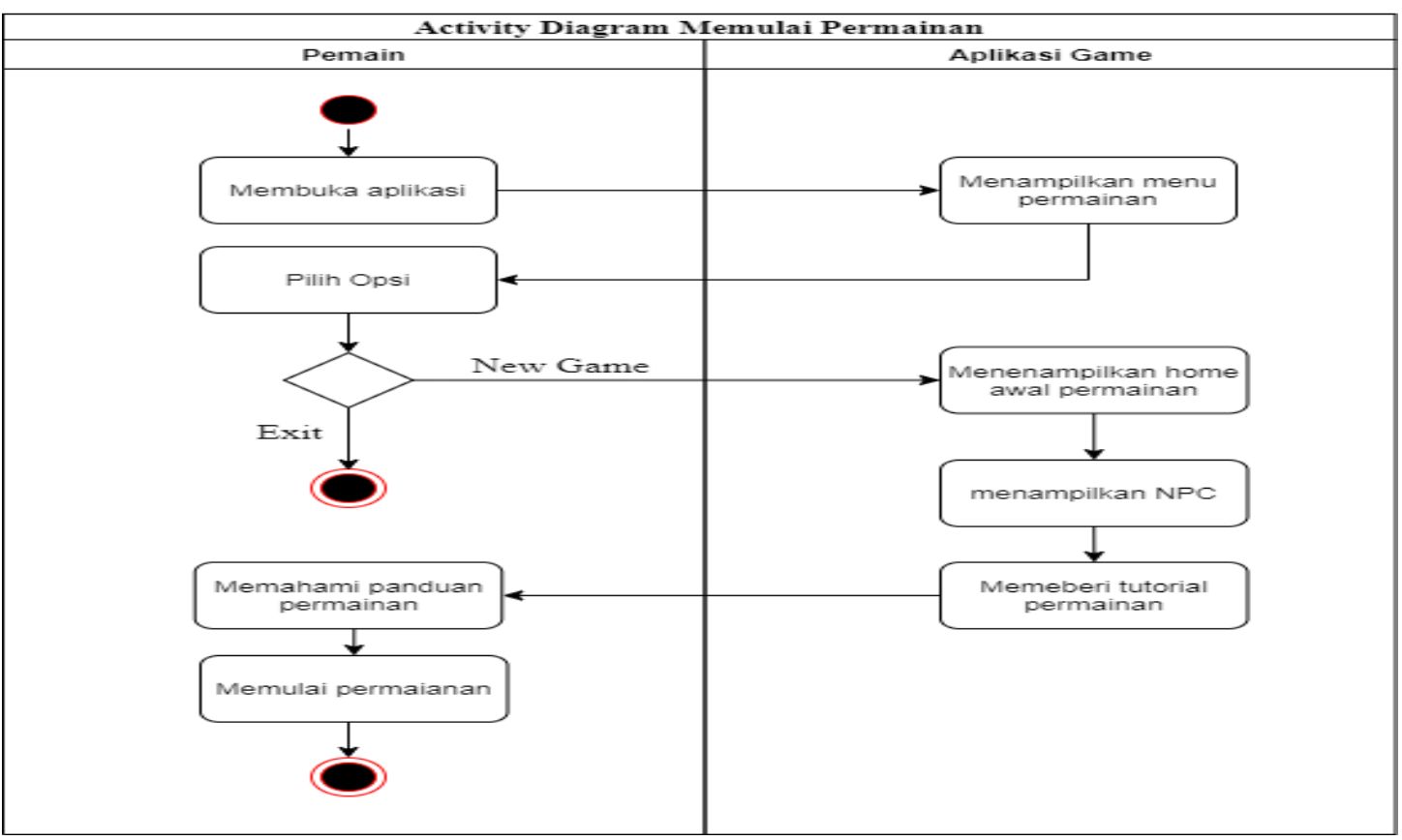

Sumber: Perancangan game edukasi (2020)

Gambar 3. Activity Diagram Memulai Permainan 
Selanjutnya adalah diagram menerima permintaan quest. Diagram ini menjelaskan tentang aktivitas pemain menemui NPC, kemudian aplikasi menampilkan dialog nama pemain, permintaan penyelesaian misi.

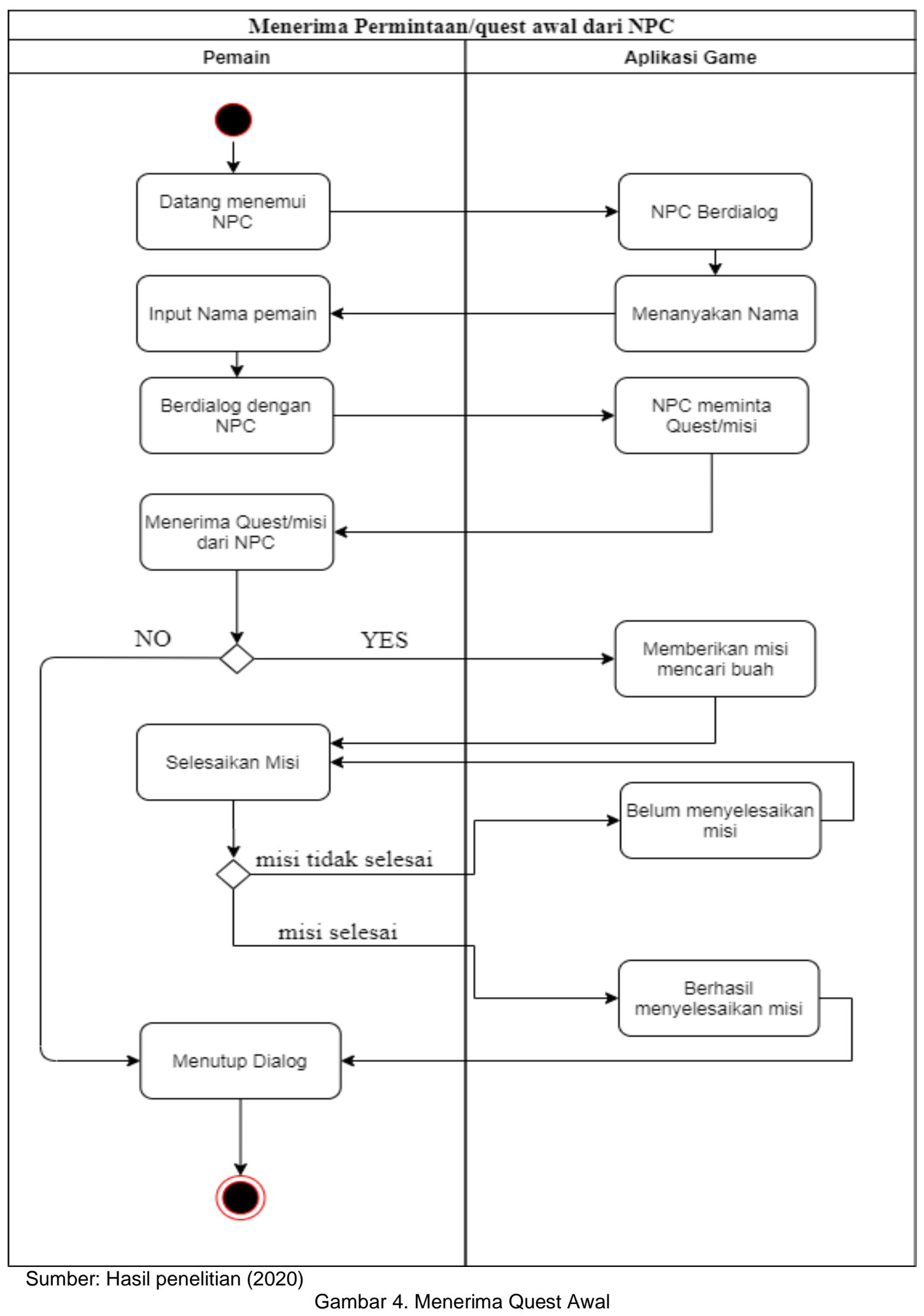


Ketiga Desain Database.diagram ini menunjakan penggunaan database yang digunakan pada game edukasi ini.

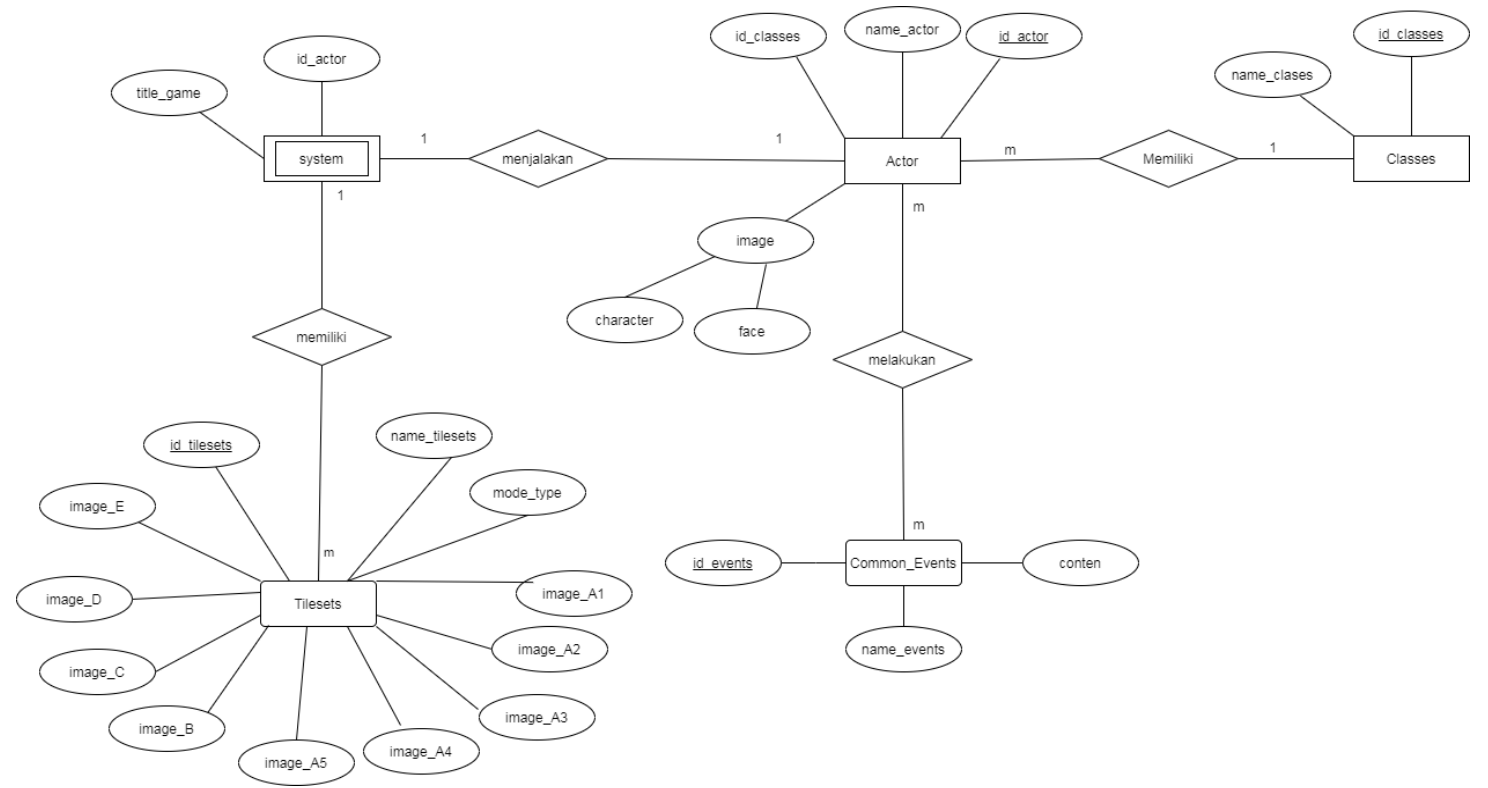

Sumber: Perancangan game edukasi (2020)

Gambar 5. Entity Diagram Game Edukasi Pengenalan Buah

Keempat User Interface. Pada tahapan ini penulis akan menampilkan halaman menu game edukasi yang dibuat, berikut halaman game edukasi.

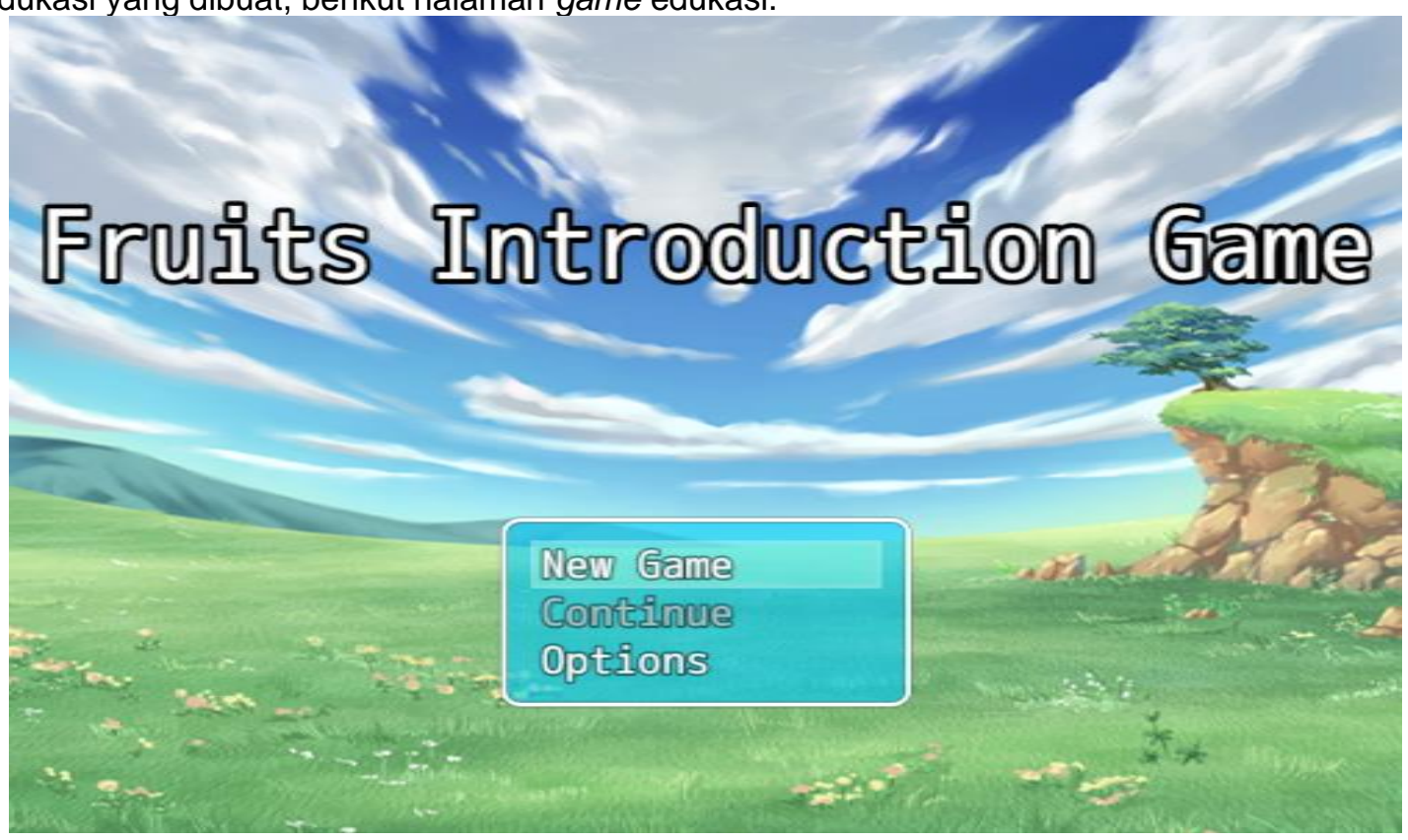

Sumber: Perancangan game edukasi (2020)

Gambar 6. Tampilan Menu Awal Game

Kelima adalah Storyboard. Pada tahap ini penulis akan menjelaskan scene storyboard yang menceritakan tampat dan kejadian dari game edukasi, antara lain:

Pertama Desa. Desa adalah tampilan scene pertama pada saat memulai permainan, lalu pemain akan diarahkan untuk berdialog dengan salah satu NPC (Non Playable Character) tersebut dan akan diminta untuk mengisi nama pemain. Desa juga adalah tempat para penduduk atau NPC yang memberikan misi/quest setiap berdialog dengan NPC tersebut. 
Kedua Goa. Goa adalah tampilan scene jalan atau akses lain menuju gunung karna didalam game akses jalan utama menuju gunung tidak bisa di lewati. Lalu didalam goa pemain akan mendengar backsound dan guna dari goa ini adalah untuk memenuhi kebutuhan dalam game seperti jalan untuk menyelesaikan misi/quest mencari buah.

Ketiga Kebun Pak teach Kebun pak teach adalah tampilan scene tempat untuk mencari buah dari misi/quest yang diberikan oleh penduduk desa atau NPC, ada backsound didalam scene kebun pak teach.

Keempat Laut. Laut adalah tampilan scene tempat untuk mencari buah dari misi/quest yang diberikan oleh penduduk desa atau NPC, ada backsound juga ditempat scene laut.

Kelima Hutan. Hutan dan rumah adalah tampilan scene tempat untuk menerima misi/quest karena disini terdapat juga karakter NPC (Non Playable Character) pemberi misi/quest dan tempat untuk menuju rumah pemain.

Keenam Ladang Buah-buahan. Ladang buah-buahan adalah tampilan scene tempat pemain mendapat informasi tentang buah-buah sebagai sarana untuk belajar mengenal buahbuahan yang terdapat di ladang buah-buahan dan juga ada karakter NPC (Non Playable Character) yang bertugas memberikan pertanyaan/quis seputar buah-buahan untuk pemain jawab.

Ketiga Pengumpulan material. Adapun desain material file dataset atau asset tambahan gambar berektensi (.png), audio berekstensi (.ogg) yang di import ke dalam game untuk memenuhi kebutuhan pembuatan game edukasi pengenalan nama buah-buahaan.

Code Generation

Text : Actor3(7), Dim, Bottom

Text : Aku belum hafal jalan, Mau kah kamu

Text : membantu ku mencari buah apel (apple)?

Show Choices : Yes, No (Window, Right, \#1, \#2)

When Yes

$\checkmark$ Control Variables : \#0001 Apple $=0$

$\checkmark$ Control Self Switch : $A=O N$

$\checkmark$ Text : Actor3(7), Dim, Bottom

: Text : waahhh... terimakasih.

: Text : aku butuh 2 apel (apple) di kebun

: Text : Pak teach..

-Text : Actor3(7), Window, Middle

: Text : Semangattt ${ }^{\wedge} \_$

$\checkmark$ Control Switches : \#0001 muncul apple = ON

$\checkmark$

: When No

- Text : Actor3(7), Dim, Bottom

: Text : baiklah jika kamu sibuk.

: End

If : Apple $=2$

$\checkmark$ Text : Actor3(7), Window, Bottom

: Text : Liv:

: Text : Wah terimakasih kamu baik sekali mencari

: Text : apple ini..

- Text : Actor3(7), Window, Bottom

: Text : semoga hari ini menjadi hari yang

: Text : lebih baik^^^

$\checkmark$ Show Balloon Icon : EV001, Heart

$\checkmark$ Control Variables : \#0007 Reputasi $+=20$

$\checkmark$ Control Self Switch : B = ON

: Else 
Text : Actor3(7), Dim, Bottom

: Text : kamu harus ke kebun Pak Teach..

: Text : Semangat^^^

: End

Terakhir adalah Testing. Penulis menggunakan pengujian black box testing pada pembuatan game dan hasil pengujian telah sesuai.

Tabel 1. Black box testing

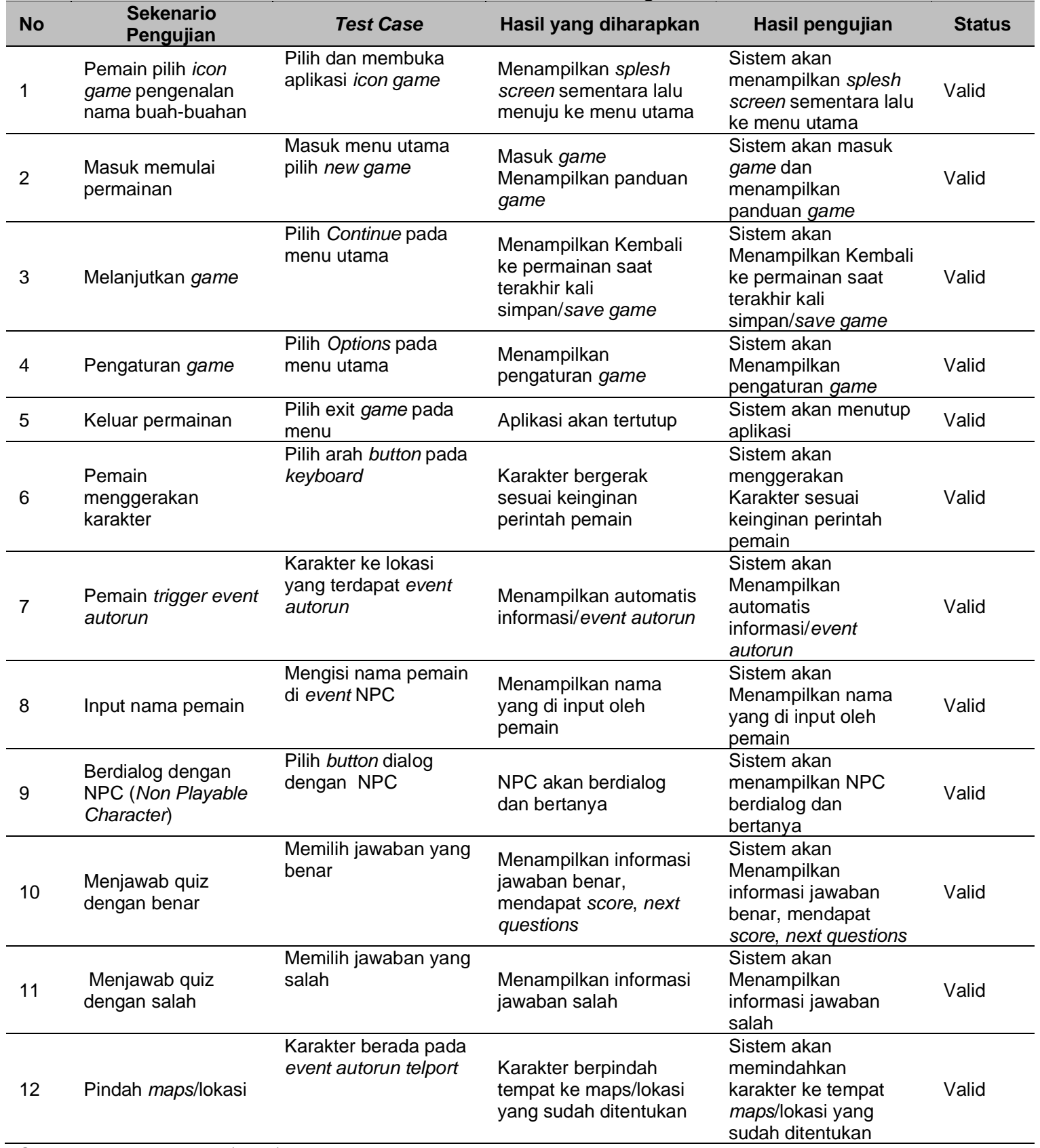

Sumber: Hasil penelitian (2020)

Pada tahap ini akan menjelaskan tentang kebutuhan hardware dan software yang akan digunakan untuk mejalankan sistem usulan. Kebutuhan tersebut yaitu komputer/ laptop dan sound audio.

Kebutuhan Hardware dan Software aplikasi yang digunakan dalam membuat aplikasi game seperti yang tampak pada table 2 . 
Tabel 2. Spesifikasi hardware dan software dalam pembuatan game

\begin{tabular}{ll}
\multicolumn{1}{c}{ Kebutuhan } & \multicolumn{1}{c}{ Keterangan } \\
\hline $\begin{array}{l}\text { Sistem Oprasi } \\
\text { Processor }\end{array}$ & Windows 7 dan lebih tinggi \\
RAM & Intel (R) core (TM) i3-3220 @ 3.30 GHZ \\
\hline Hardisk & $4.00 \mathrm{~GB}$ \\
\hline Monitor & $500 \mathrm{~GB}$ \\
Mouse & SVGA \\
\hline VGA & Standart \\
\hline DirectX Version & $1 \mathrm{~GB}$ \\
\hline Keyboard & DirectX 11 \\
\hline SoundCard PCl & 107 Key \\
\hline Software Program & Standart USB \\
\hline Sumber: Hasil penelitian (2020) & RPG Maker MV, Adobe Audition, Adobe PhotoShop. \\
\hline
\end{tabular}

Sedangkan kebutuhan Hardware dan Software aplikasi yang digunakan dalam pengoperasian aplikasi game seperti yang tampak pada table 3 .

Tabel 3. Spesifikasi Hardware dan Software Client/Pemain

\begin{tabular}{ll}
\multicolumn{1}{c}{ Kebutuhan } & \multicolumn{1}{c}{ Keterangan } \\
\hline Sistem Operasi & Windows (windows 7 tasted) \\
Processor & AMD E1-200 APU with Radeon \\
\hline RAM & 2.00 GB \\
\hline Monitor & SVGA \\
\hline Keyboard & 107 key \\
Mouse & Standart \\
\hline SoundCard PCl & Standart USB \\
\hline VGA & 1.00 GB \\
\hline Sumber: Hasil penelitian (2020) &
\end{tabular}

\section{Kesimpulan}

Setelah penulis melakukan analisis dan uji coba terhadap Game edukasi pengenalaan nama buah-buahan dalam bahasa Inggris menggunakan RPG maker MV. Penulis memberikan solusi dengan membuat game ini dan mencoba menarik kesimplan dari game yang dibuat ini. Pertama dengan pembuatan game edukasi ini diharapakan dapat memudahkan dan membantu anak-anak atau orang-orang dalam belajar mengenal buah-buahan dalam bahasa Inggris. Kedua dengan pembuatan game edukasi ini diharapkan dapat menarik anak-anak dalam belajar mengenal buah-buahan dalam bahasa Inggris. Ketiga Dengan pembuatan game edukasi ini diharapkan dapat mengurangi candu anak-anak dalam bermain game yang merusak dan tidak ada unsur positif dan edukasi. Keempat Dengan pembuatan game edukasi ini diharapakan dapat menghibur dan bermanfaat.

\section{Referensi}

[1] M. S. Khairy, D. Herumurti, and I. Kuswardayan, "Analisis Pengaruh Penggunaan Game Edukasi pada Penguasaan Kosakata Bahasa Asing dengan Studi Kasus Game Edukasi Bahasa Arab," Khazanah Inform. J. IImu Komput. dan Inform., vol. 2, no. 2, p. 42, Dec. 2016, doi: 10.23917/khif.v2i2.2137.

[2] M. Ridwan and P. Prasetyawan, "RANCANG BANGUN APLIKASI PERMAINAN ADVENTURE OF FRUNIMAL UNTUK EDUKASI BAHASA INGGRIS BERBASIS ANDROID," Simetris J. Tek. Mesin, Elektro dan Ilmu Komput., vol. 8, no. 2, p. 763, Nov. 2017, doi: 10.24176/simet.v8i2.1599.

[3] D. Nurdiana, D. Rahadian, and A. Suryadi, "GAME EDUKASI PENGENALAN NAMA BUAH DAN SAYURAN DALAM BAHASA INGGRIS UNTUK SEKOLAH DASAR," Teknol. PEMBELAJARAN, vol. 2, no. 1, 2017, doi: 10.31980/TP.V2l1.110.

[4] Ariesto Hadi Sutopo, Teknologi informasi dan komunikasi dalam pendidikan. Yogyakarta: Graha IImu, 2012.

[5] Darrin Perez, Beginning RPG Maker MV, 2nd Edition. San Lorenzo, Puerto Rico: Darrin Perez, 2016.

[6] Darrin Perez, Beginning RPG Maker VX Ace. San Lorenzo, Puerto Rico: Darrin Perez, 2014.

[7] R. Sistem, H. Prasetiyo, I. Widaningrum, and I. P. Astuti, "Game Edukasi Math \& Trash Berbasis Android dengan Menggunakan,” J. RESTI (Rekayasa Sist. dan Teknol. 
Informasi), vol. 1, no. 10, pp. 5-11, 2020

[8] S. L. Rahayu and F. Fujiati, "Penerapan Game Design Document dalam Perancangan Game Edukasi yang Interaktif untuk Menarik Minat Siswa dalam Belajar Bahasa Inggris," J. Teknol. Inf. dan IImu Komput., vol. 5, no. 3, p. 341, Aug. 2018, doi: 10.25126/jtiik.201853694.

[9] A. Latubessy and M. N. Ahsin,"Hubungan Antara Adiksi Game Terhadap Keaktifan Pembelajaran Anak Usia 9-11 Tahun," Simetris J. Tek. Mesin, Elektro Dan Ilmu Komput., Vol. 7, No. 2, P. 687, Nov. 2016, Doi: 10.24176/Simet.V7i2.782.

[10] M. A. Pranata,"Game Balinese Fruit Shooter Berbasis Virtual Reality Sebagai Media Pembelajaran Di Taman Kanak-Kanak," Edutech, Vol. 16, No. 3, P. 305, Feb. 2018, Doi: 10.17509/E.V16i3.8544. 